\title{
HSP70 as a Biomarker: an Excellent Tool in Environmental Contamination Analysis—a Review
}

\author{
Cristina Moreira-de-Sousa • Raphael Bastão de Souza • \\ Carmem Silvia Fontanetti
}

Received: 19 March 2018 / Accepted: 19 July 2018 / Published online: 30 July 2018

(C) Springer Nature Switzerland AG 2018

\begin{abstract}
HSP70 are the most studied proteins and among all HSPs are highlighted due to their high sensitivity and abundance, as well as being ubiquitously expressed and associated with all subcellular compartments. For this reason, this work specifically approaches HSP70, since its multiple responsibilities actively participate in the homeostasis of all living organisms and its rapid response to any agent stressor is efficient in assessing environmental pollution/contamination processes. HSP70, heat shock proteins thus classified according to their molecular weight of $70 \mathrm{kDa}$, are proteins that have maintained their structures conserved from the most primitive to the most complex organisms. They belong to the chaperone family, which comprises proteins with different structures that share a common function. In general, they participate in the process of correct folding of proteins; however, it has been described that they also participate in numerous complex processes of metabolism; its synthesis can usually be increased or decreased under stressful conditions. The classical activation of this protein is due to the increase in environmental temperature, but several factors can trigger the gene expression process of this protein, not only as the increase or decrease of heat or cold, but also the exposure to substances of a chemical nature, physical or biological (metals, metabolism inhibitors,
\end{abstract}

C. Moreira-de-Sousa $(\varangle) \cdot$ R. B. de Souza $\cdot$ C. S. Fontanetti Department of Biology, Biosciences Institute, UNESP (São Paulo State University), Av. 24-A, 1515, Rio Claro, São Paulo 13506-900, Brazil

e-mail: cris.sousa.bio@hotmail.com chemotherapeutic agents, inflammatory and infectious processes, processes leading to cell death, the cycle of cell division itself and growth factors, cellular mechanisms considered normal). Given the broad repercussion of these proteins in metabolic processes and in organism physiology, numerous studies have evaluated the HSP70 production under adverse conditions, highlighting their connection to pollution and environmental contamination. Hence, this work aimed to literature review the vast array of HSP70 metabolic functions and its possible applications as biomarkers in the evaluation of contaminated environments by compiling the different physiological responses observed in various animal groups exposed to different conditions.

Keywords Molecular biomarker - Cellular stress . Environmental stress $\cdot$ Bioindicators $\cdot$ Heat shock proteins

\section{Introduction}

The physiological response of an organism to exposure to a stressor of any nature triggers a process of synthesis of specific proteins to repair possible damage caused by this exposure. This synthesis of proteins involved with the "quality control" of cells is well established among all living organisms, in addition to being a process that has maintained a high degree of conservation from the prokaryotes to the eukaryotes (Hamer et al. 2004; Mayer and Bukau 2005). 
At first, the synthesis of these proteins was associated only with exposure to high temperatures, that is, thermal shock, since their discovery was due to the observation in Drosophila melanogaster cells during exposure to high temperatures. Exposure to heat was responsible for producing a new pattern in the thickening of the chromosomes, providing the creation of specific transcription sites for the synthesis of new proteins. This showed the stress generated by the heat induced the expression of certain genes and, consequently, the activation of a new class of proteins, the heat shock proteins (HSPs) (Morimoto and Fodor 1984; Meyer and Silva 1999).

After numerous studies, these proteins were named molecular chaperones, coming from the French term chaperon that means "lady-in-waiting." These proteins perform the function that defines them, since they assist the processes related to the correct protein folding, preventing incorrect folding and improper aggregation. Thus, the function usually attributed to chaperones is that of assisting the newly formed proteins to assume the proper configuration in order to perform their tasks in the cell cycle. This is undoubtedly a task of extreme importance, since if protein folding errors occur, there may be the formation of protein aggregates and consequently impairment of protein functions. One example of these errors is the development of Alzheimer's and Parkinson's disease, the most well-known conformational diseases (Alves Filho 2008; Castro et al. 2013).

After their initial discovery, HSPs have been shown to cover a broad list of tasks beyond their involvement with heat shock responses, also assisting in response to ischemia: presence of trace metals (Somero 1995); presence of several chemical, physical, and biological inducers, including the cycle of cell division itself, growth factors, cell proliferation, and cellular processes considered normal (Feder et al. 1992); acting on cell protection against the deleterious effects of endotoxins (Chi and Mestril 1996); on exposure to ultraviolet radiation (Simon et al. 1995); in cases of tumorigenicity (Jäättela 1995); apoptosis (Wyatt et al. 1996; Jäättela et al. 1998; Jäättela 1999; Böttger et al. 2008); in pathologies, such as viral, bacterial, and parasitic infections; autoimmune diseases; metabolic poisons, which in some way compromise protein function (Welch 1992; Cellura et al. 2006); homeostatic changes such as changes in salinity; hypoxia; and oxidative stress, among others (Feder et al. 1995; Feder and Hofmann 1999; Yenari et al. 1999; Golli-Bennour and Bacha 2011).
HSPs, classified according to their molecular mass, comprise the families of small HSPs: from 15 to $30 \mathrm{kDa}$, with HSP27 being the most prominent, since it is one of the main inducible HSPs (Didelot et al. 2007; Ciocca and Calderwood 2005). Families of large HSPs with up to $100 \mathrm{kDa}$ are the HSP100, HSP90, HSP70, and HSP60 (Feder et al. 1995; Patruno et al. 2001; Yenari et al. 1999). Among these, HSP70 stands out because it presents a rapid and significant synthesis in face of several stressors. It is also involved in numerous cellular events and, for this reason, has been widely used as a biomarker for various analyzes (Jonsson et al. 2006; Liu et al. 2015; Souza et al. 2017).

Most HSPs are not only located in cellular compartments, such as mitochondria, reticulum, and cytosol, but can also be detected in the extracellular environment. While intracellular HSPs mainly play the cytoprotective role, others in the extracellular environment and plasma membrane, they have immunogenic properties and may induce a pro or anti-inflammatory response. They may elicit an immune modulated response both by the adaptive immune system and by the innate (Didelot et al. 2007). Schmitt et al. (2007) describes that HSP27, HSP70, HSP90, and GRP78 proteins are found in the extracellular medium with immunogenic function.

In the face of these characteristics that the HSPs have and in particular the HSP70, numerous works have been carried out using this protein as a biomarker, being able to signal possible environmental changes expressed in the organisms exposed to the diversity of the environment where they are, through the expression of their gene and consequent activation of the protein, being able to be increased or decreased according to the situation of the organism (Köhler et al. 1992; Zanger et al. 1996; Nadeau et al. 2001; Mello et al. 2012; SilvaZacarin et al. 2012; Taylor et al. 2013; AnsoarRodríguez et al. 2016; Coelho et al. 2017).

In this context, this review aimed to compile data on the role of the HSP70 heat shock protein and its applicability as a biomarker in several organisms. The characteristics that the HSP70 present become these proteins as the most studied (Moyes and Schulte 2010), are activated in all cellular reactions (Sabirzhanov et al. 2012) and reside in all subcellular compartments (Sharma and Masison 2009; Evans et al. 2010), are abundant and highly sensitive, expressed ubiquitously, and are extremely important for cellular repair machinery (Mishra and Palai 2014); thus, participation in the homeostasis of all living organisms is its crucial function (Sable et al. 2018); these points 
justify the choice of these proteins for the present study and in particular in studies in which HSP70 stands out in situations of environmental contamination. This group of proteins shows a rapid response when a particular organism is exposed to stress, so it has been widely used in environmental analysis. A summary of the results obtained from HSP70 analyses in some animals exposed to stressor agents listed in this text is seen in Table 1.

\section{HSP70: functioning}

As mentioned above, HSP70 proteins are central components of a cellular network of molecular chaperones and catalysts of protein folding processes. They have a cell cleaning function integrated in folding and signal transduction pathways which allow them to revise the structures of newly synthesized proteins and repair unsuccessful protein conformations. These processes are handled by specialized HSP70 chaperones, which result from the amplification and diversification of Hsp70 genes during evolution. For this to occur, cochaperones are often required. They are recruited by HSP70 chaperones to fulfill specific cellular functions, and as a result of their cooperation, they broaden their spectrum of activity, creating complex repair machinery (Mayer and Bukau 2005).

The role on non-native protein folding may be divided in three related activities: prevention and aggregation, folding into the native state and solubilization, and refolding of aggregated proteins (Ben-Zvi and Goloubinoff 2001; Mayer and Bukau 2005). These processes are of fundamental importance for stable cellular operation.

Several studies point out that HSP70 heat shock proteins present other functions as important as their stress specific roles. Their presence was observed during early development of Drosophila, during rat embryogenesis, and in embryonic carcinoma cells (Velasquez et al. 1980; Bensaude and Morange 1983; Morimoto and Fodor 1984; Arya et al. 2007).

Given these observations, researchers have endeavored to better understand the other possible functions of HSP70. Morimoto and Fodor (1984) suggested that one way of understanding if these proteins act in cells in a normal state would be to survey HSP70 expression under unaltered conditions, in the absence of heat shock.

The heat shock response (HSR) is characterized by the rapid transcription and translation of a series of proteins from the HSPs family (Feder et al. 1995). Thus, following the path of these proteins in their different destinations revealed the other functions attributed to HSP70.

From a molecular point of view, the mechanisms of action of HSP70 generally are based on an N-terminal ATPase domain of $45 \mathrm{kDa}$, a C-terminal binding domain of $25 \mathrm{kDa}$, which is subdivided into a $\beta$-sandwich subdomain and a $\mathrm{C}$-terminal $\alpha$-helical subdomain. The sequence alignment of the HSp70 proteins reveals differences that may translate into functional differences. A shift in the ATPase cycle can be observed, changing between the ATP state with low affinity and a rapid energetic cost to the substrate or the ADP state with high affinity and low energy cost for the substrate (Harrison et al. 1997; Mayer and Bukau 2005).

A more detailed description of how the molecular structure of HSP70 is established within cells predicts that the substrate binding domain (SBD), which occurs in the $\mathrm{C}$-terminal region, controls the access to the substrate via the $\mathrm{C}$-terminal structure. This structure functions as a cap/lid and exposes the binding site to the peptides. A hydrophobic flexible bond binds the SBD domain to the N-terminal domain with ATPase activity (NBD). The nucleotide (which can be found in ATP or ADP state) binds to the NBD domain by association with the binding affinity of the SBD domain. Therefore, the allosteric regulation of this site, as well as the interaction with auxiliary proteins (co-chaperones) and nucleotide exchange factors (NEF), depends on the conformation of the SBD site. The evaluation of NBD structure of several members of the HSP70 family has demonstrated that this domain is highly conserved and has little contribution in protein specificity. The SBD site and accessory proteins define the specificity role (Jiang et al. 2007; Vos et al. 2008; Kampinga and Craig 2010; Wisniewska et al. 2010).

Highly conserved, HSP70 presents great structural similarity when compared between species. For example, HSP70 presents $73 \%$ similarity with Drosophila and $50 \%$ with Escherichia coli (Feder et al. 1995).

The common characteristic of genes HSPs is the induction of transcription by heat shock elements (HSF) and homotrimeric DNA binding transcription factor, heat shock factor (HSF). The stressor agents may be of different origins as environmental, chemical or pathophysiological stresses, but activation of the response will always be homotrimerization of DNA binding. The stressor agents may be of different origins 
Table 1 Summary of the results obtained from HSP70 analyses in animals exposed to stressor agents listed in the text

\begin{tabular}{|c|c|c|c|}
\hline Organisms & HSP70 level & Stressor agents & References \\
\hline \multicolumn{4}{|l|}{ Insects } \\
\hline Apis mellifera & Increase & Acaricide & Silva-Zacarin et al. (2006) \\
\hline Drosophila melanogaster & Increase & Mixture of pesticides & Doganlar and Doganlar (2015) \\
\hline $\begin{array}{l}\text { Ochesella bifasciata; } \\
\text { Tomocerus flavescens }\end{array}$ & $\begin{array}{l}\text { Variations in } \\
\text { different situations }\end{array}$ & Metals & Köhler et al. (1999) \\
\hline Chorthippus brunneus & Variations & Metals & Augustyniak et al. (2009) \\
\hline Drosophila melanogaster & Increase & Metals & Doganlar et al. (2014) \\
\hline Aedes albopictus & Increase & Metals & Braeckman et al. (1997) \\
\hline Spodoptera exigua & Increase & Metals & Kafel et al. (2012) \\
\hline Tetrix tenuicornis & - & Metals & Warchalowska-Sliwa et al. (2005) \\
\hline Musca domestica & - & Metals & Borowska and Pyza (2011) \\
\hline Sarcophaga crassipalpis & Increase & Diapause & Yocum (2001) \\
\hline Leptinotarsa decemlineata & Decrease & Diapause & Yocum (2001) \\
\hline Omphisa fuscidentalis & Decrease & Diapause & Tungjitwitayakul et al. (2008) \\
\hline \multicolumn{4}{|l|}{ Diplopods } \\
\hline $\begin{array}{l}\text { Glomeris marginata, } \\
\text { Cylindroiulus punctatus, } \\
\text { and Tachypodoiulus niger }\end{array}$ & - & Metals & Köhler et al. (1992) \\
\hline Julus scandinavius & Increase & Metals & Zanger et al. (1996) \\
\hline Rhinocricus padbergi & Increase & Vinasse and biosolid & Coelho et al. (2017) \\
\hline \multicolumn{4}{|l|}{ Crustaceans } \\
\hline Calamus finmarchius & Variations & Diapause & Aruda et al. (2011) \\
\hline \multicolumn{4}{|l|}{ Annelids } \\
\hline Lumbricus terrestres & Decrease & Metals & Nadeau et al. (2001) \\
\hline \multicolumn{4}{|l|}{ Mollusks } \\
\hline Sphincterochila sp & Variations & Natural annual cycle of activities & Mizrahi et al. (2012) \\
\hline Saccostrea glomerata & Decrease & High temperature and metals & Taylor et al. (2013) \\
\hline Crassostrea gigas & Increase & Toxins & Mello et al. (2012) \\
\hline Crassostrea gigas & Increase & Toxins & Mello et al. (2013) \\
\hline Lymnaea stagnalis & Increase & Pharmaceutical mixtures & Gust et al. (2013) \\
\hline Pinctada fucata & Increase & Bacterial infection & WANG et al. (2009) \\
\hline Mytilus galloprovincialis & Increase & Seasonal changes & Li et al. (2009) \\
\hline Deroceras reticulatum & Increase & Metals & Köhler et al. (1996) \\
\hline Mytilus sp. & Increase & Organic contaminants & Jonsson et al. (2006) \\
\hline Mytilus galloprovincialis & Increase & $\begin{array}{l}\text { Environmental pollution correlated to } \\
\text { seasonal variations, } \mathrm{pH} \text {, and salinity }\end{array}$ & Mi'covi' et al. (2009) \\
\hline Chamelea gallina & Increase & $\begin{array}{l}\text { Variation in oxygen level, temperature, } \\
\text { salinity, and B[a]P (Benzo[a]pyrene) } \\
\text { concentration }\end{array}$ & Monari et al. (2011) \\
\hline \multicolumn{4}{|c|}{ - } \\
\hline Oreochromis mossambicus & Variations & Stress caused by animal agglomeration & Dini et al. (2006) \\
\hline Oreochromis niloticus & Increase & Insecticide imidacloprid & Ansoar-Rodríguez et al. (2016) \\
\hline $\begin{array}{l}\text { Squalis torgalensis and } \\
\text { Squalis carolitertii }\end{array}$ & Variations & Seasonal changes & Jesus et al. (2013) \\
\hline Oncorhynchus mykiss & Increase & Metals & Söyüt et al. (2012) \\
\hline Mugil cephalus & Increase & Xenobiotics & Ekambaram and Narayanan (2017) \\
\hline
\end{tabular}

- no change was observed in the synthesis of HSP70 in individuals 
as environmental, chemical, or pathophysiological stresses, but activation of the response will always be homotrimerization of DNA binding which may be from HSF or its isoforms (HSF1 in mammals, for example). Activation of HSF proteins in response to stress is a process involving a few steps, i.e., the conversion of an inactive monomer to homotrimer, nuclear accumulation, DNA binding, and activation of the target gene. However, little is known about the precise mechanisms by which the stress signal is transmitted and interpreted by stress-responsive HSF proteins in order to activate transcription to the homotrimeric DNA binding form (Ahn and Thiele 2003).

The study of physiological stress through the analysis of HSP70 represents a useful tool to quantify and predict levels of stress in organisms. Thus, it leads to an understanding of environmental changes that limit the distribution of these organisms and how much variation they could withstand in a stress situation (Tomanek 2008, 2010).

Del Razo et al. (2001) reviewed the ability of arsenic compounds to modulate and/or accumulate stress proteins. In this work, the authors observed the physiological consequences of arsenic-induced stress and monitored the effects resulting from exposure to arsenic in humans and other organisms. In most cases, the induction of stress proteins depends on the ability of arsenic to reach its valence, the type of exposure, with arsenite being the largest inducer of HSP in various organs and systems. HSP70 induction to arsenic is rapid and has a dosedependent response.

HSP70, in addition to its most common function, also acts efficiently in situations of cytotoxicity, as it plays a cryoprotective role against deleterious effects on cells. This is true regardless of the process and for conditions generated by internal and external factors (Chi and Mestril 1996; Ansoar-Rodríguez et al. 2016; Coelho et al. 2017).

\section{HSP70 Gene Expression Changes in Organisms Exposed to Toxins}

\subsection{Insects}

In insects, HSP30, HSP70, and HSP90 are the three best known groups of stress proteins (Denlinger et al. 2001). It is known that they have important functions in insects, differing from species to species and even within the same species according to the physiological and environmental conditions where they occur (King and
MacRae 2015). HSP70 is the most studied group and present the best results in stress responses in this class (Denlinger et al. 2001).

Several species of insects can be used as bioindicators of environmental pollution. HSP70 marking in particular has been widely used in environmental stress and/or contamination situations.

Silva-Zacarin et al. (2006) presented an analysis of HSP70 heat shock proteins in Apis mellifera bees, a species which are constantly exposed to pesticides. According to the authors, these stress conditions in the field might induce morphological and physiological alterations. Therefore, immunodetection of HSP70 is an important additional tool to the results obtained for side effects of acaricides (rotenone) and oxalic acid exposure. It was demonstrated that HSP70s were synthesized in the cytoplasm and/or the nucleus of secretory gland cells.

It is known that pesticides are one of the main contaminants of groundwater and drinking water, being usually introduced into the environment through anthropic practices and agricultural neglect. Since water is the final destination of pesticides, these substances usually appear as complex mixtures and are hardly found as individual compounds (Silins and Högberg 2011).

In this sense, Doganlar and Doganlar (2015) demonstrated that Drosophila melanogaster exposed to a mixture of pesticides (molinate, thiobencarb, linuron, phorate, primiphos-methyl, fenvalerate, and lambdacyhalothrin) that are commonly found in water at concentrations of $0.1,0.5$, and 1 part per billion ( $\mathrm{ppb}$ ) showed increased HSP gene expression at all concentrations, among other changes. The production of HSP70s, unlike the other HSPs evaluated, increased after exposure of the animals to concentrations of 0.5 and $1 \mathrm{ppb}$. This work suggested that, considering the changes in HSP levels, the permissible limits of pesticide concentrations for drinking water described in the regulations of several countries are potentially cytotoxic. The observations presented by the authors serve as a basis for the re-evaluation of these limits.

Köhler et al. (1999) induced the synthesis of HSP70 as a marker for cell stress in two species of collembolans (Orchesella bifasciata and Tomocerus flavescens) exposed to a metal concentration gradient near a bronze factory. The population of severely polluted areas, fed with seaweed containing high concentrations of metals, presented low values of HSP70. According to the 
authors, levels below the detection limit of HSP70 in samples exposed to contaminated seaweed are probably due to pathological cell damage. This allowed the authors to conclude that the differences in tolerance between individuals and the heterogeneous distribution of metals in the litter may explain the large intra-specific variability found in HSP70 levels.

Augustyniak et al. (2009) evaluated the level of HSP70 in the 1st instar of Chorthippus brunneus grasshoppers located in different cities in Poland. Among the cities, there were both unpolluted (Pilica, place of reference) and polluted habitats (Olkusz, Szopienice). The grasshoppers were additionally exposed to several doses of zinc (one of the most abundant pollutant in the studied sites) and also studied during the diapause process of these animals. Great variation was observed in the expression level of HSP70 gene when comparing the sites included in the study and the adverse situations in which the animals were. The level of HSP70 in the body of the offspring depended on the place of origin, with the highest expression of HSP70 found in the bodies of larvae that hatched from eggs laid by young females from Pilica. In contrast, a low level of HSP70 was found in larvae from polluted sites, especially in the progeny of young females. The application of zinc during diapause influenced the level of HSP70 in locust larvae; however, the type of change depended on the place of origin of the insects. In larvae from the reference site and, to a lesser extent, in Olkusz, the increase in the level of HSP70 after zinc treatment was more pronounced. The grasshoppers from Szopienice showed no change in the expression of HSP70 after exposure to low zinc dosage, but a higher dosage caused a reduction of protein expression. According to the authors, all these observations may be a result of maternal heritability, but it cannot be ruled out that a possible adaptation of the animals may have occurred. Thus, it can be observed that the synthesis of the HSP70 protein can signal different responses in different situations.

Trace metals found in water can cause a number of human health damages, as well as compromise the mental and physical development of children (Benham and Ling 2011). Because of the toxic effects of trace metals, governments and different agencies linked to public health have set limits on the amount of metals that are allowed in water destined for consumption. Therefore, Doğanlar et al. (2014) exposed adult individuals of D. melanogaster to a mixture of four trace metals $(\mathrm{Fe}, \mathrm{Cu}, \mathrm{Cd}$, and $\mathrm{Pb})$ in three different concentrations.
The higher dose and the lower dose were stipulated according to the limits allowed in drinking water in order to evaluate whether these limits would in fact cause changes in bioindicator animals.

The observations were that the expression of the Hsps genes was altered as a result of the increased exposure time and that the HSP70 obtained a higher level of expression when compared to the other HSPs (HSP60, HSP26, HSP83) also expressed in the organism. In view of these responses, along with the other analyses obtained, the authors concluded that the mixture of the four metals caused a genotoxic effect in the organism (Doğanlar et al. 2014).

Braeckman et al. (1997) and Kafel et al. (2012) observed an increase in the production of HSP70 in Aedes albopictus and Spodoptera exigua that were exposed to the metal cadmium. However, some studies suggest that metal-induced expression of HSP70 varies from species to species.

In a study conducted by Warchalowska-Sliwa et al. (2005), individuals of the Orthoptera species Tetrix tenuicornis were collected from a polluted area with concentrations of copper, zinc, lead, and cadmium that were up to 41 times higher than the control group. The results showed that there was no significant increase in the induction of HSP70. Similar result was found by Borowska and Pyza (2011) when Musca domestica (Diptera) was exposed to the same metals in laboratory conditions. No change in HSP70 synthesis was observed in treated subjects, regardless of whether the concentration was low or high.

\subsection{Diplopoda}

According to Knigge et al. (2014), little is known about the stress proteins in soil invertebrates. Even less is known about the Diplopoda class, particularly on HSPs, despite its significant contribution to the detritivorous fauna of the soil.

The first study carried out with the purpose of analyzing the HSPs in the group was developed by Köhler et al. (1992). The diplopod species (Glomeris marginata, Cylindroiulus punctatus, and Tachypodoiulus niger) were used to perform the experiments in the laboratory, where they were contaminated with lead for 41 days. The results showed that both the contaminated group and the control group had the same pattern of HSPs. The authors explained the induction of proteins in the control group by stress caused by captivity. 
Subsequently, Zanger et al. (1996) induced HSP70 expression in adult individuals of Julus scandinavius exposing them to litter contaminated with different concentrations of $\mathrm{Cd}^{2+}$. The increased concentration of $\mathrm{Cd}^{2+}$ in the food resulted in high levels of HSP70, which according to the authors was indicative of a proteotoxic condition.

Coelho et al. (2017) exposed Rhinocricus padbergi to two residues widely used as fertilizers: biosolids and sugarcane vinasse. The animals showed increased immunostaining for HSP70 when exposed to such residues, revealing the cytoprotective function of HSP70s.

\subsection{Crustaceans}

As in insects, stress proteins are also found in the diapause process in crustaceans. Aruda et al. (2011) verified the synthesis of these proteins in the marine copepod Calamus finmarchius during the diapause process and when exposed to stress. Eight heat shock proteins were identified: HSP21, HSP22, HSP26, HSP90, and four forms of HSP70 (HSP70 A, B, C and D), which were characterized according to the stress response to the manipulation process and in association with diapause.

HSP21, HSP22, and HSP70A (cytosolic subfamily) were induced by stress from the manipulation of the animals. HSP22 had a high production in animals with deep diapauses, protecting proteins from degradation during this process and playing its role in short-term stress. In addition to the role in stress response, the synthesis of HSP70 and HSP90 varied during the crustacean molting cycle and thus aided in regulating the developmental delay associated with diapause in C. finmarchicus.

\subsection{Annelids}

Nadeau et al. (2001) carried out an evaluation for HSP70 as a biomarker of several soil pollutants using the earthworm Lumbricus terrestres. One of the objectives of the study was to evaluate whether a doseresponse relationship could be established and whether the response to the stress observed was specific. They were exposed to chloroacetamides, pentachlorophenol, and metals $\left(\mathrm{Pb}^{++}, \mathrm{Cd}^{++}, \mathrm{Cu}^{++}, \mathrm{Hg}^{++}\right)$, which induced the expression of the HSP70 gene in the animal's midgut. It was detected a decrease in HSP70 synthesis in the muscle tissues near the middle of the body that were exposed to metals.

HSP analysis in L. terrestres tissues, particularly in the midgut, has been shown to be an adequate and sensitive test for adverse effects on earthworms and has shown a good level of reproducibility despite some individual variations. For the authors, the induction of HSP70 in worms represents not only a good biomarker with a broad spectrum of exposure but also a biomarker of effect, since known toxic agents alter the expression of the gene in the tissues of these animals, and not just a simple accumulation of HSPs. Thus, the detection of HSP70 in earthworms may be an early warning marker for the presence of potentially harmful agents in soils.

\subsection{Mollusks}

The phylum Mollusca is one of the largest groups and is of great importance in the animal kingdom. Most of these animals live in fresh or salt water and must face intense environmental disturbances to maintain homeostasis, a situation generally described as a cause of stress. The production of acute-phase proteins, such as HSPs, is considered a classic response against stress factors. For this reason, HSP70s from mollusks are of particular interest, and also because on their diversity, sequence characters, and expression profiles in hemocytes under several types of stresses (Wang et al. 2013).

Most information on the synthesis of HSP70 in mollusks was obtained from tissue analysis, including gills, digestive glands, muscle, mantle, and hemocytes. Like most hemolymph, hemocytes comprise the major component of nonspecific defense mechanisms, so they are closely involved in a series of cellular immune responses (Mello et al. 2012; Wang et al. 2013).

Synthesis of HSP proteins can occur without an external stressor. Mizrahi et al. (2012) have suggested in their studies that in terrestrial snails of the Sphincterochila species, HSP70 is involved in the natural annual cycle of activities. Estivation, survival strategies during desiccation and heat stress, and adaptation of land snails to different habitat are some examples of activities that generate the development of different strategies for expression of HSP70 in response to stress.

HSP70 synthesis in mollusk hemocytes was extensively investigated as a response to several environmental stressors, such as high temperature, metals (Taylor et al. 2013), toxins (Mello et al. 2012; Mello et al. 2013), pharmaceuticals (Gust et al. 2013), bacterial infections 
(Wang et al. 2009), and seasonal changes (Li et al. 2009). The expression profiles are generally divided into three types: upregulated, invariable, and downregulated. The upregulation of HSP70 proteins in mollusks hemocytes generally exhibits a pattern that is clearly dose-dependent and time-dependent (Mello et al. 2012).

Köhler et al. (1996) exposed adult specimens of the slug species Deroceras reticulatum to sublethal concentrations of lead, cadmium, and zinc. After 3 weeks of exposure, the tests showed accumulation of all these metals in the animals, accompanied by an increase in HSP70 protein. They showed that the applied technique serves as a versatile tool to evaluate the stress reactions in invertebrates in response to relevant environmental toxins.

Jonsson et al. (2006) investigated the possible use of cytoskeletal components as biomarkers of organic pollution in mussels. The authors also evaluated the expression of HSP70 protein in mussels exposed to isolated crude oil and to mixtures with alkyl phenols and polycyclic aromatic hydrocarbons (PAHs), brominated flame retardants (BDE-47), bisphenol A, and diallyl phthalate. Protein expression was strongly induced in all exposure groups.

Mi' covi' ce al. (2009) estimated the concentration of heavy metals in four sites in the industrial zone of Kvarneriam Bay, in the northern Adriatic Sea, by studying the mussel Mytilus galloprovincialis. In this work, the alterations were correlated with seasonal variations in environmental temperature, $\mathrm{pH}$, and salinity, as well as the expression of metallothioneins (MTs) and heat shock proteins (HSP70) in the digestive tract of mussels. The results demonstrated that the induction of MTs and HSP70 were highly affected by the contamination by $\mathrm{Pb}, \mathrm{Hg}$, and $\mathrm{Cd}$ present in the sea sediments. This implies that these stress proteins can be biomarkers of the power of marine pollution.

Monari et al. (2011) evaluated the heat shock protein HSP70 expression in response to physical and chemical stress in Chamelea gallina, a bivalve mollusk from the coast of Italy. Mollusks were exposed to different experimental conditions: variation in oxygen levels $(48 \mathrm{~h}$ of anoxia followed by $24 \mathrm{~h}$ of normoxic recovery), variation in temperature $\left(20,25,30{ }^{\circ} \mathrm{C}\right.$ for 7 days $)$, variation in salinity $(28,34,40 \%$ ofor 7 days), and $\mathrm{B}$ [a]P exposure at $0.5 \mathrm{mg} / \mathrm{L}$ concentrations for $24 \mathrm{~h}$ over a period of 7 and 12 days. In all exposure situations, HSP70 demonstrated significant upregulation under anoxic conditions at elevated temperatures, low salinity, and presence of $\mathrm{B}[\mathrm{a}] \mathrm{P}$. The authors considered the induction of HSP70 as an adaptation mechanism associated with changes in environmental parameters, as well as the presence of xenobiotics. Overproduction of HSP70 can also be induced by protein damage due to stress factors. The involvement of the protein as a physiological response was useful as an early warning of environmental stress caused by pollution.

\subsection{Fish}

Dini et al. (2006) monitored HSP70 gene expression in the Mozambique tilapia (Oreochromis mossambicus) during confinement and during stress caused by animal agglomeration. After the tests, it can be concluded that in reality, the increase or decrease of HSP70 expression in the stressed fish was modified in the organ and the duration-dependent stress exhibits minimal subjective fluctuations. Evaluating the experiment as a whole, the authors suggest that the expression of HSP70 could be an indicator of stress state in fish when measured in organs with significant responses.

Söyüt et al. (2012) evaluated the gene expression of HSP70 in rainbow trout (Oncorhynchus mykiss) after exposure to some metals. Expression of the Hsp70 gene was increased in the presence of the metal ions such as cobalt, copper, zinc, and silver. At the end of $48 \mathrm{~h}$ exposure, the expression level was high for all metals.

Jesus et al. (2013) carried out studies with two species of freshwater fish of the genus Squalis (Squalis torgalensis and Squalis carolitertii). The authors observed that these animals are subject to intense seasonal variations daily and changes occur in the expression of HSP70 genes. The authors observed that the $S$. torgalensis species increased HSP70 expression at $35{ }^{\circ} \mathrm{C}$ while $S$. carolitertii showed no increase in gene expression, but some deaths were recorded. The two species have different ways of dealing with changes in temperature.

Ansoar-Rodríguez et al. (2016) analyzed the liver of Oreochromis niloticus (Nile tilapia) exposed to the insecticide imidacloprid, widely used in sugarcane crops. Analysis of the HSP70 of the exposed animals demonstrated a considerable increase in the immunostaining protein, suggesting that the insecticide caused a cytotoxic reaction in the liver cells of the Nile tilapias.

Ekambaram and Narayanan (2017) evaluated the cytoprotective effect of HSP70 on fish brain on the stress effect on xenobiotic pollutants. Significant 
elevation in the HSP70 level observed by the authors is indicative that the upregulation of HSP70 has a cytoprotective role during stress induced by xenobiotics in the fish brain.

\section{Conclusion}

Considering the various responses from numerous studies compiled here, we concluded that the monitoring of both the increase and decrease in gene expression and consequent activation and synthesis of HSP70 proteins has great potential to warn about environmental disturbance caused by numerous substances. These substances may interfere negatively in the physiology of both invertebrates and vertebrates. The analysis of different techniques used to identify the presence of the HSP70 protein as molecular biomarker has proven to be an excellent tool in investigations of this nature.

Funding Information The authors thank CAPES (Coordenação de Aperfeiçoamento de Pessoal de Nível Superior), and Cnpq (Conselho Nacional de Pesquisas) for financial support.

\section{References}

Alves Filho, M. (2008). Chaperonas, as 'damas de companhia' das proteínas. Jornal da Unicamp, 413, 9.

Ahn, S. G., \& Thiele, D. J. (2003). Redox regulation of mammalian heat shock factor 1 is essential for Hsp gene activation and protection from stress. Genes \& Development, 17, 516528.

Ansoar-Rodríguez, Y., Christofoletti, C. A., Correia, J. E., Souza, R. B., Moreira-de-Sousa, C., Marcato, A. C. C., BUENO, O. C., Malaspina, O., Silva-Zacarin, E. C. M., \& Fontanetti, C. S. (2016). Liver alterations in Oreochromis niloticus (Pisces) induced by insecticide imidacloprid: Histopathology and heat shock protein in situ localization. Journal of Environmental Science and Health. Part B. Pesticides, Food Contaminants, and Agricultural Wastes, 51, 881-887.

Aruda, A. M., Baumgartner, M. F., Reitzel, A. M., \& Tarrant, A. M. (2011). Heat shock protein expression during stress and diapause in the marine copepod Calanus finmarchicus. Journal of Insect Physiology, 57, 665-675.

Arya, R., Mallik, M., \& Lakhotia, S. C. (2007). Heat shock genes - integrating cell survival and death. Journal of Biosciences, 32(3), 595-610.

Augustyniak, M., Tarnawska, M., Babczyn'ska, A., \& Augustyniak, M. (2009). Hsp70 level in progeny of aging grasshoppers from variously polluted habitats and additionally exposed to zinc during diapause. Journal of Insect Physiology, 55, 735-741.
Benham, B., \& Ling, E. J. (2011). Virginia household water quality program: shock chlorination: disinfecting private household water supply systems. http://www.wellwater.bse. vt.edu/files/Well_Informed_Newsletter-Mar2011.pdf. Accessed 10 November 2017.

Bensaude, O., \& Morange, M. (1983). Spontaneous high expression of heat shock proteins in mouse embryonal carcinoma cells and ectoderm from day 8 mouse embryo. EMBO (Eur Mol Biol Organ) J, 2, 173-177.

Ben-Zvi, A. P., \& Goloubinoff, P. (2001). Review: mechanisms of disaggregation and refolding of stable protein aggregates by molecular chaperones. Journal of Structural Biology, 135, 84-93.

Borowska, J., \& Pyza, E. (2011). Effects of heavy metals on insect immunocompetent cells. Journal of Insect Physiology, 57(6), 760-770.

Böttger, S., Jerszyk, E., Low, B., \& Walker, C. (2008). Genotoxic stress-induced expression of p53 and apoptosis in leukemic clam hemocytes with cytoplasmically sequestered p53. Cancer Research, 68, 777-782.

Braeckman, B., Raes, H., \& Van Hoye, D. (1997). Heavy-metal toxicity in an insect cell line. Effects of cadmium chloride, mercuric chloride and methylmercuric chloride on cell viability and proliferation in Aedes albopictus cells. Cell Biology and Toxicology, 13(6), 389-397.

Castro, S. V., Lobo, C. H., Figueiredo, J. R., \& Rodrigues, A. P. R. (2013). Proteínas de choque térmico hsp70: estrutura e atuação em resposta ao estresse celular. Acta Veterinaria Brasilica, 7(4), 261-271.

Cellura, C., Toubiana, M., Parrinello, N., \& Roch, p. (2006). HSP70 gene expression. In Mytilus galloprovincialis hemocytes is triggered by moderate heat shock and Vibrio anguillarum, but not by V. splendida or Micrococcus lysodeikticus. Development \& Comparative Immunology, 30(11), 984-997.

Ciocca, D. R., \& Calderwood, S. K. (2005). Heat shock proteins in cancer: diagnostic, prognostic, predictive, and treatment implications. Cell Stress \& Chaperones, 10(2), 86-103.

Chi, S., \& Mestril, R. (1996). Stable expression. Of a human HSP70 gene in a rat myogenic cell line confers protection against endotoxin. American Physiological Society, C1017C1021.

Coelho, M. P. M., Moreira-de-Sousa, C., Souza, R. B., AnsoarRodríguez, Y., Silva-Zacarin, E. C. M., \& Fontanetti, C. S. (2017). Toxicity evaluation of vinasse and biossolid sample in diplopod midgut: heat shock protein in situ localization. Environmental Science and Pollution Research. https://doi. org/10.1007/s11356-017-9754-2.

Del Razo, L. M., Quintanilla-Vega, B., Brambila-Colombres, E., Calderón-Aranda, E., Manno, M., \& Albores, A. (2001). Stress proteins induced by arsenic. Toxicology and Applied Pharmacology, 177, 132-148.

Denlinger, D. L., Rinehart, J. P., Yocum, G. D. (2001). Stress proteins: A role in insect diapause? In: D.L. Denlinger, D.L., J.M. Giebultowicz, J.M., Saunders, D.S. (Org.). Insect timing: circadian rhythmicity to seasonality (pp. 155-171). Elsevier.

Didelot, C., Lanneau, D., Brunet, M., Joly, A. L., Thonel, A. D., Chiosis, G., \& Garrido, C. (2007). Anti-cancer therapeutic approaches based on intracellular and extracellular heat 
shock proteins. Current Medicinal Chemistry, 14, 28392847.

Dini, L., Lanubile, R., Tarantino, P., Mandich, A., \& Cataldi, E. (2006). Expression of stress proteins 70 in tilapia (Oreochromis mossambicus) during confinement and crowding stress. Italian Journal of Zoology, 73(2), 117-124.

Doğanlar, Z. B., Doğanlar, O., \& Tabakçıŏlu, K. (2014). Genotoxic effects of heavy metal mixture in Drosophila melanogaster: expressions of heat shock proteins, RAPD profiles and mitochondrial DNA sequence. Water, Air, and Soil Pollution, 225, 1-14.

Doganlar, O., \& Doganlar, Z. B. (2015). Responses of antioxidant enzymes and heat shock proteins in drosophila to treatment with a pesticide mixture. Arch Biol Sci, 67, 869-876.

Evans, C. G., Chang, L., \& Gestwicki, J. E. (2010). Heat shock protein 70 (Hsp70) as an emerging drug target. Journal of Medicinal Chemistry, 53(12), 4585-4602.

Ekambaram, P., \& Narayanan, M. (2017). Upregulation of HSP70 extends Cytoprotection to fish brain under xenobiotic stress. Journal of FisheriesSciences.com, 11(1), 11-20.

Feder, J. H., Rossi, J. M., Solomon, J., Solomon, N., \& Lindquist, S. (1992). The consequences of expressing hsp70 in Drosophila cell at normal temperatures. Genes \& Development, 6, 1402-1413.

Feder, E. M., Parsell, A. D., Lindquist, S. (1995). The stress response and stress proteins. In: J. J. Lemasters \& C. Oliver (Ed), Cell biology of trauma (pp. 177-191). CRC Press Boca Raton.

Feder, M. E., \& Hofmann, G. E. (1999). Heat-shock proteins, molecular chaperones, and ecological physiological. Annual Review of Physiology, 61, 243-282.

Golli-Bennour, E. E., \& Bacha, H. (2011). Hsp70 expression as biomarkers of oxidative stress: Mycotoxins' exploration. Toxicology, 287, 1-7.

Gust, M., Fortier, M., Garric, J., Fournier, M., \& Gagné, F. (2013). Effects of short-term exposure to environmentally relevant concentrations of different pharmaceutical mixtures on the immune response of the pond snail Lymnaea stagnalis. Science of the Total Environment, 445-446, 210-218.

Hamer,B., Hamer, D. P., Müller, W. E. G., Batel, R. (2004). Stress70 proteins in marine mussel Mytilus galloprovincialis as biomarkers of environmental pollution: a field study. Environment International 30 (7):873-882

Harrison, C. J., Hayer-Hartl, M., Di Liberto, M., Hartl, F. U., \& Kuriyan, J. (1997). Crystal structure of the nucleotide exchange factor GrpE bound to the ATPase domain of the molecular chaperone DnaK. Science, 276, 431-435.

Jäättela, M. (1995). Over-expression of hsp70 confers tumorigenicity to mouse fibrosarcoma cells. International of Journal of Cancer, 60, 689-693.

Jäättela, M., Wissing, D., Kokholm, K., Kallunki, T., \& Egeblad, M. (1998). Hsp70 exerts its anti-apoptotic function downstream of caspase-3-like proteases. The EMBO Journal, 17(21), 6124-6134.

Jäättela, M. (1999). Escaping cell death: survival proteins in cancer. Experimental Cell Research, 248, 30-43.

Jesus, T. F., Inácio, A., \& Coelho, M. M. (2013). Different levels of hsp70 and hsc70 mRNA expression in Iberian fish exposed to distinct river conditions. Genetics and Molecular Biology, 36(1), 61-69.
Jiang, J., Maes, E. G., Taylor, A. B., Wang, L., Hinck, A. P., Lafer, A. M., \& Sousa, R. (2007). Structural basis of J cochaperone binding and regulation of Hsp70. Molecular Cellular Biology, 28(3), 422-433.

Jonsson, H., Schiedek, D., \& Goksoyr, A. (2006). Expression of cytoskeletal proteins, cross-reacting with anti-CYP1A, in Mytilus sp. exposed to organic contaminants. Aquatic Toxicology, 78S, S42-S48.

Kafel, A., Nowak, A., Bembenek, J., SzczygieŁ, J., Nakonieczny, M., \& Świergosz-Kowalewskab, R. (2012). The localization of HSP70 and oxidative stress indices in heads os Spodoptera exigua larvae in a cadmium-exposed population. Ecotoxicology and Environmental Safety, 78, 22-27.

Kampinga, H. H., \& Craig, E. A. (2010). The Hsp70 chaperone machinery: J-proteins as drivers of functional specificity. Nature reviews-Molecular cell biology, 11(8), 579-592.

King, A. M., \& MacRae, T. H. (2015). Insect heat shock proteins during stress and diapause. Annual Review of Entomology, $60,59-75$.

Knigge, T., Bachmann, L., \& Köhler, H. R. (2014). An introncontaining, heat-inducible stress-70 gene in the millipede Tachypodoiulus niger (Julidae, Diplopoda). Cell Stress and Chaperones, 19, 741-747.

Köhler, H. R., Eckwert, H., Triebskorn, R., \& Bengtsson, G. (1999). Interaction between tolerance and $70 \mathrm{kDa}$ stress protein (hsp70) induction in collembolan populations exposed to long-term metal pollution. Applied Soil Ecology, $11,43-52$.

Köhler, H. R., Triebskorn, R., Stöcker, W., Kloetzel, P. M., \& Alberti, G. (1992). The $70 \mathrm{kD}$ heat shock protein (hsp70) in soil invertebrates: a possible tool for monitoring environmental toxicants. Archives of Environmental Contamination and Toxicology, 22(3), 334-338.

Köhler, H. R., Rahman, B., Gräff, S., Berkus, M., \& Triebskorn, R. (1996). Expression of the stress-70 protein family (hsp70) due to heavy metal contamination in the slug, Deroceras reticulatum: an approach to monitor sublethal stress conditions. Chemosphere, 33(7), 1327-1340.

Li, H., Toubiana, M., Monfort, P., \& Roch, P. (2009). Influence of temperature, salinity and E. coli tissue content on immune gene expression in mussel: Results from a 2005-2008 survey. Developmental \& Comparative Immunology, 33(9), 974 979.

Liu, T., Pan, L., Cai, Y., \& Miao, J. (2015). Molecular cloning and sequence analysis of heat shock proteins 70 (HSP70) and 90 (HSP90) and their expression analysis when exposed to benzo(a)pyrene in the clam Ruditapes philippinarum. Gene, $555,108-118$.

Mayer, M. P., \& Bukau, B. (2005). Hsp70 chaperones: Cellular functions and molecular mechanism. Cellular and Molecular Life Sciences, 62, 670-684.

Mello, D. F., Oliveira, E. S., Vieira, R. C., Simões, E., Trevisan, R., Dafre, A. L., \& Barraco, M. A. (2012). Cellular and transcriptional responses of Crassostrea gigas Hemocytes exposed in vitro to brevetoxin (PbTx-2). Marine Drugs, 10, 583-597.

Mello, D. F., da Silva, P. M., Barracco, M. A., Soudant, P., \& Hégaret, H. (2013). Effects of the dinoflagellate Alexandrium minutum and its toxin (saxitoxin) on the functional activity and gene expression of Crassostrea gigas hemocytes. Harmful Algae, 26, 45-51. 
Meyer, T. N., \& Silva, A. L. (1999). Resposta celular ao estresse. Revista da Associação Médica Brasileira, 45(2), 181-188.

Mi'covi'c, V., Bulog, A., Ku ‘ci 'c, N., Jakovac, H., \& Rado`sevi'c-Sta`si', B. (2009). Metallothioneins and heat shock proteins 70 in marine mussels as sensors of environmental pollution in Northern Adriatic Sea. Environmental Toxicology and Pharmacology, 28, 439-447.

Mishra, S. R., \& Palai, T. K. (2014). Importance of heat shock protein 70 in livestock-at cellular level. Journal of Molecular Pathophysiology, 3(2), 30-32.

Mizrahi, T., Heller, J., Goldenberg, S., \& Arad, Z. (2012). Heat shock proteins and survival strategies in congeneric land snails (Sphincterochila) from different habitats. Cell Stress and Chaperones, 17, 523-527.

Monari, M., Foschi, J., Rosmini, M. G., \& Serrazanetti, G. P. (2011). Heat shock protein 70 response to physical and chemical stress in Chamelea gallina. Journal of Experimental Marine Biology and Ecology, 397, 71-78.

Morimoto, R., \& Fodor, E. (1984). Cell-specific expression of heath shock proteins in chicken reticulocytes and lymphocytes. The Journal of Cell Biology, 99, 1316-1323.

Moyes, C. D., \& Schulte, P. M. (2010). Princípios de fisiologia animal. pp. 938. Editora: Artmed Editora S. A.

Nadeau, D., Plante, I., Morrow, G., \& Tanguay, R. M. (2001). Evaluation for Hsp70 as a biomarker of effect of pollutants on the earthworm Lumbricus terrestres. Cell Stress Chaperon, 6, 153-163.

Patruno, M., Thorndyke, M. C., Carnevali, M. D. C., Bonasoro, F., $\&$ Beesley, P. W. (2001). Growth factor, heat-shock proteins and regeneration in echinoderms. Journal of Experimental Biology, 204, 843-848.

Sabirzhanov, B., Stoica, B. A., Hanscom, M., Piao, C. S., \& Faden, A. L. (2012). Over-expression of HSP70 attenuates caspasedependent and caspase independent pathways and inhibits neuronal apoptosis. Journal of Neurochemistry, 123(4), 542554.

Sable, A., Rai, K. M., Choudhary, A., Yadav, V. K., Agarwal, S. K., \& Sawant, S. V. (2018). Inhibition of heat shock proteins HSP90 and HSP70 induce oxidative stress, suppressing cotton fiber development. Scientific Reports, 8, 1-17.

Schmitt, E., Gehrmann, M., Brunet, M., Multhoff, G., \& Garrido, C. (2007). Intracellular and extracellular functions of heat shock proteins: repercussions in cancer therapy. Journal of Leukocyte Biology, 81, 15-27.

Sharma, D., \& Masison, D. C. (2009). Hsp70 structure, function, regulation and influence on yeast Prions. Protein \& Peptide Letters, 16(6), 571-581.

Silins, I., \& Högberg, J. (2011). Combined toxic exposures and human health: biomarkers of exposure and effect. International Journal of Environmental Research and Public Health, 8, 629-647.

Silva-Zacarin, E. C. M., Chauzat, M. P., Zeggane, S., Drajnudel, P., Schurr, F., Faucon, J. P., Malaspina, O., \& Engler, J. A. (2012). Protocol for optimization of histological, histochemical and immunohistochemical analyses of larval tissues: application in histopathology of honey bee. Current microscopy contributions to advances in science and technology, 1 , 696-703.

Silva-Zacarin, E. C. M., Gregorc, A., Silva de Moraes, R. L. M. (2006). In situ localization of heat-shock protein and cell death labelling in the salivary gland of acaricide-treated honey bee larvae. Apidologie, 37, 507-516

Simon, M. M., Reikerstorfer, A., Schwarz, A., Krone, C., Luger, T. A., Jäättela, M., \& Schwarz, T. (1995). Heat shock protein 70 overexpression affects the response to ultraviolet light in murine fibroblasts: Evidence for increased cell viability and suppression of cytokine release. The Journal of Clinical Investigation, 95, 926-933.

Somero, G. N. (1995). Protein and temperature. Annual Review of Physiology, 57, 43-68.

Söyüt, H., Beydemir, S., Ceyhun, S. B., Erdogan, O., \& Kaya, E. D. (2012). Changes in carbonic anhydrase activity and gene expression of Hsp70 in rainbow trout (Oncorhynchus mykiss) muscle aft er exposure to some metals. Turkish Journal of Veterinary and Animal Science, 36(5), 499-508.

Souza, R. B., Moreira-de-Sousa, C., Christofoletti, C. A., Souza, C. P., Fontanetti, C. S. (2017). Impactos de resíduos (vinhaça e biossólido) lançados no cultivo de cana-de-açúcar em representantes da fauna edáfica. In: Fontanetti, C.S. \& Bueno, O.C. (Org.). Cana-de-açúcar e seus impactos: uma visão acadêmica (pp. 197-214). Bauru, SP: Canal 6.

Taylor, D. A., Thompson, E. L., Nair, S. V., \& Raftos, D. A. (2013). Differential effects of metal contamination on the transcript expression of immune-and stress-response genes in the Sydney Rock oyster, Saccostrea glomerata. Environmental Pollution, 178, 65-71.

Tomanek, L. (2008). The importance of physiological limits in determining biogeographical range shifts due to global climate change: the heat shock response. Physiological and Biochemical Zoology, 81, 709-717.

Tomanek, L. (2010). Variation in the heat shock response and its implication for predicting the eVect of global climate change on species' biogeographical distribution ranges and metabolic costs. Journal of Experimental Biology, 213, 971-979.

Tungjitwitayakul, J., Tatun, N., Singtripop, T., \& Sakurai, S. (2008). Characteristic expression of three heat shockresponsive genes during larval diapause in the bamboo borer Omphisa fuscidentalis. Zoological Science, 25(3), 321-333.

Velazquez, J. M., DiDomenico, B. J., \& Lindquist, S. (1980). Intracellular localization of heat shock proteins in Drosophila. Cell, 20(3), 679-689.

Vos, M. J., Hageman, J., Carra, S., \& Kampinga, H. H. (2008). Structural and functional diversities between members of the human HSPB, HSPH, HSPA, and DNAJ chaperone families. Biochemistry, 47(27), 7001-7011.

Wang, L., Yang, C., \& Song, L. (2013). The molluscan HSP70s and their expression in hemocytes. International Scientific Journal, 10, 77-83.

Wang, Z., Wu, Z., Jian, J., \& Lu, Y. (2009). Cloning and expression of heat shock protein 70 gene in the haemocytes of pearl oyster (Pinctada fucata, Gould 1850) responding to bacterial challenge. Fish \& Shellfish Immunology, 26(4), 639-664.

Warchalowska-Sliwa, E., Niklinska, M., Görlich, A., Michailova, P., \& Pyza, E. (2005). Heavy metal accumulation, heat shock protein expression and cytogenetic changes in Tetrix tenuicornis (L.) (Tetrigidae, Orthoptera) from polluted areas. Environmental Pollution, 133, 373-381.

Welch, W. (1992). Mammalian stress response: cell physiology, structure/function of stress proteins, and implications for medicine and disease. Physiological Reviews, 72, 10631081. 
Wisniewska, M., Karlberg, T., Lehtiö, L., Johansson, I., Kotenyova, T., Moche, M., \& Schüler, H. (2010). Crystal structures of the ATPase domains of four human Hsp70 isoforms: HSPA1L/Hsp70-hom, HSPA2/Hsp70-2, HSPA6/ Hsp70B', and HSPA5/BiP/GRP78. PLoS One, 5(1), 8625.

Wyatt, S., Mailhos, C., \& Latchman, D. S. (1996). Trigeminal ganglion neurons are protected by the heat shock proteins hsp70 and hsp90 from thermal stress but not from programmed cell death following nerve growth factor withdrawal. Brain Research Molecular Brain Research, 39, 52-56.
Yenari, M. A., Giffard, G. R. G., Sapolsky, R. M., \& Steinberg, G. K. (1999). The neuroprotective potential of heat shock protein 70 (HSP70). Molecular Medicine Today, 5, 525-531.

Yocum, G. D. (2001). Differential expression of two HSP70 transcripts in response to cold shock, thermoperiod, and adult diapause in the Colorado potato beetle. Journal of Insect Physiology, 47(10), 1139-1145.

Zanger, M., Alberti, G., Kuhn, M., \& Kölher, H. R. (1996). The stress-70 protein family in diplopods: induction and characterization. Journal of Comparative Physiology B, 165, 622-627. 